\title{
SIMULATION OF MERCURY TRANSPORT FROM GOLD MINING ACTIVITIES IN PELAWAN RIVER, SAROLANGUN
}

\author{
Yaumal Arbi ${ }^{1}$, Eka R. Aidha ${ }^{2}$, \\ ${ }^{1}$ Program Studi Teknik Sipil, Universitas Negri Padang, Indonesia; \\ ${ }^{2}$ Program Studi Teknik Pertambangan, Sekolah Tinggi Teknologi Industri Padang, Indonesia
}

\begin{abstract}
The use of mercury as a material for bonding and separating gold with sand in gold mining has the potential to contaminate ground water and river water. In this study, the distribution of mercury parameters from gold mining occurred in Pelawan river, Sarolangun regency, Jambi Province. To determine contaminants flow, In this study mathematical modeling mercury was carried out using 1-dimensional analytic model based on advection-dispersion equation in surface water. The concentration of mercury in water is measured 3 times for calibration and model validation. From the measurements at some point, it is known that the Pelawan river is contaminated with mercury, the mercury value obtained is $0.007 \mathrm{mg} / 1$, this value is far past the quality standard based on Government Regulation No.82 of 2001 on the management of water quality and water pollution control. Mercury simulation showed that the longer time ( $t$ ), a constant input of pollutants that create greater pollution load. As a result, the concentration of pollutants in the larger $t$ will decline at a greater distance. The resultsof mercyry simulation with $\mathrm{k}=0,22 /$ day showed that the mercury model is quite close to the mercury concentration observations.
\end{abstract}

Keywords: Advection, mercury, dispersion, Pelawan River

\section{INTRODUCTION}

Illegal gold mining activity in Pelawan river continue to rise. Officially, gold mining activities are not permitted by the government, both provincial and district levels. One of the most troublesome problems surrounding sites is mercury. The use of mercury as a material to bind and separate gold seeds with untreated sands, mud and water will have an impact on gold miners and communities around the river mines where the mercury used is usually discharged into Pelawan river.

in rivers is an efficient tool in water resource management (Benedini, 2011). Mathematical models can be useful for water resource utilization, reduce exhaust pollutants from certain sources, the estimated impact of technological change on the environment, development of monitoring methods and facilities, and management of environmental quality (Kachiashvili etal., 2007). Therefore it is necessary to conduct research to determine pollution of Pelawan river, one of them is by using mathematical modeling to know the spread of pollutant.

Attempts to model the transport phenomena of pollutants was done because the river water quality management will be a very helpful tool for monitoring river water quality (Chefin Suprian, 2014). In addition this model is expected to be a reference to control water pollution in the river so that the quality of the river environment can always be maintained.

\section{METHODOLOGY}

\subsection{Location of Study}

The research location in Pelawan river of Sarolangun Regency of Jambi Province. Geographically, the Pelawan river lies at $-2^{\circ} 37^{\prime} 01$ "north latitude and $102^{\circ} 59^{\prime} 28$ east longitude. Figure 1 shows the location of the river used as the research site.

From the initial survey, three sampling points were chosen to find out how the pollutant concentration changes along the Pelawan river segment as shown in Figure 2. At that point the water sample is considered to be perfectly mixed. The sampling point is also taken on the main stream of the Pelawan river. 


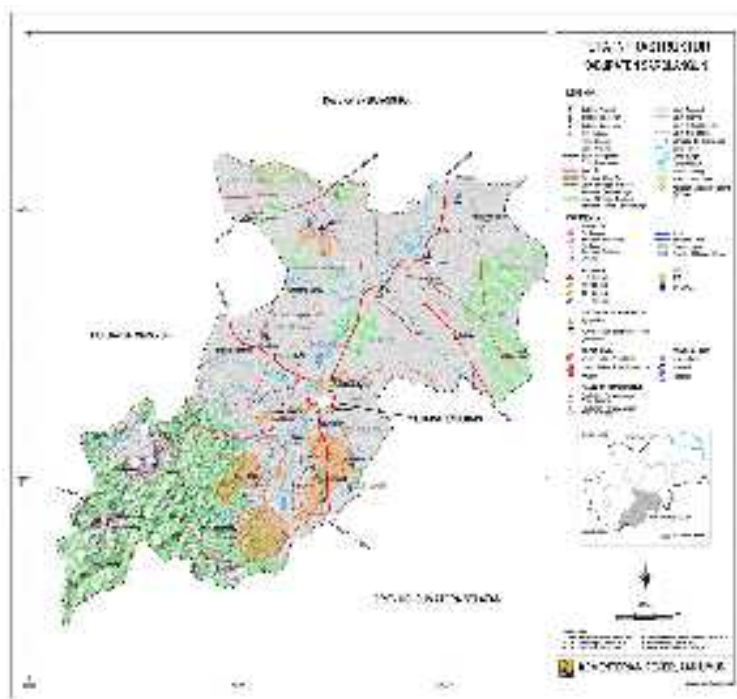

Fig.1 Research location (Ministry of Public Works, 2012)

\subsection{Primary Data Collection}

Primary data collection is done by taking samples directly to the field. The quality of the water body is considered relatively stable so that the

sampling of water using the grab sample method or the instantaneous water sample is, the water sample is taken at one take from one location. Data collection will be done at 3 points in Pelawan river segment which is considered to represent river condition. Primary data collected include river hydrogeometric data and Mercury concentration in water and sediment.

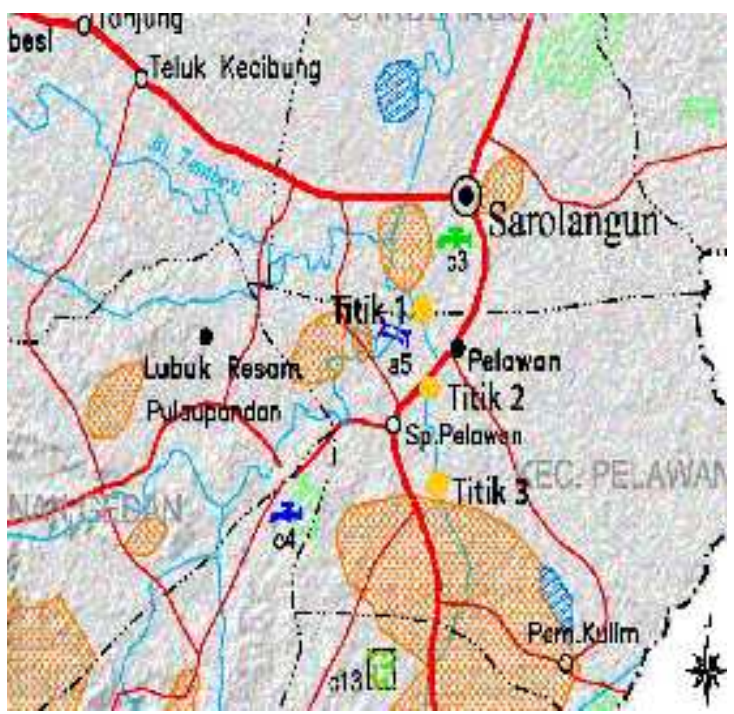

Fig.2 point of sampling

\subsection{Hydrology and River Geometry}

The characteristics of river hydrogeometry that need to be looked for include: (Thomman et al., 1987):

- $\quad$ Average river depth $(\mathrm{H})$
- $\quad$ Average river flow velocity (u)

- $\quad$ River width (B)

- Area of river cross section (A)

- Tilt of channel (S)

- $\quad$ River flow (Q)

\subsection{Concentration Mercury}

Mercury concentration was obtained by using Indonesian standard 6989.78: 2011 method and measurement of concentration by using AAS (Ato mic Absorption Spectrofotometry).

\subsection{Model Application}

To know the movement of pollutants in the river used one-dimensional models for $\mathrm{COD}$ and $\mathrm{Cu}$. Based on Schnoor (1996) and Ani (2011) advectiondiffusion equation used in the one-dimensional models of pollutants transport indicated by Equation (1).

$$
\frac{\partial}{\partial}+{ }^{x} \frac{\partial x}{\partial x}=E x \frac{\partial^{\sqrt[3]{2}}}{\partial x^{\sqrt{3}}}+\bar{E}-
$$

Where:

$\mathrm{C}=$ local concentration $(\mathrm{mg} / \mathrm{L})$;

$E_{x}=$ longitudinal dispersion coefficient ( $\mathrm{m}^{2} /$ second); $\mathrm{u}_{\mathrm{x}}=$ longitudinal dispersion velocity $(\mathrm{m} / \mathrm{second})$; $\mathrm{S}=$ pollutant source $(\mathrm{mg} / \mathrm{L}) ; \mathrm{R}=$ reaction $(\mathrm{mg} / \mathrm{L})$.

The reaction group $\mathrm{R}$ shows the biological, physical, and chemical processes that affect the spread of pollutants. The pollutant to be used in this transport model is Mercury. Mercury has $\mathrm{R}=0$ because it belongs to a conservative pollutant compound that is, in its dissemination process considered to have no chemical and biological processes.

Assuming a semi-infinite pollutant source, the analytical solution of the one-dimensional transport equation used is (Fjeld et al, 2006):

$$
\begin{aligned}
& (x, \overline{2})
\end{aligned}
$$

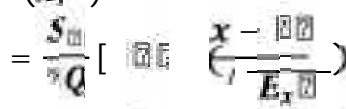

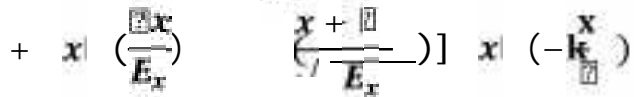

With $\mathrm{S}_{0}$ is the amount of mass of contaminants released per unit time. The value of $S_{0}$ is obtained from the initial concentration multiplied by the discharge. The current velocity used results from field measurements. The concentration of Mercury used as the initial value is the result of field measurement.

Based on Fischer et al. (1979) in Thomman (1987) the equation to estimate longitudinal dispersion coefficient in rivers and streams : 


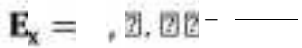

$$
\begin{aligned}
& \mathbf{U}^{*}=\sqrt{\mathrm{g} \mathbf{\mathrm { H }}} \quad \stackrel{-L}{\mathrm{~B}} \boldsymbol{U}^{*}
\end{aligned}
$$

To estimate the value of the reaeration rate constants, the $\mathrm{O}^{\prime}$ Connors \& Dobbins equations (Chapra, 1997) are used:

$$
K_{a}=3,93 \frac{u^{0.5}}{H^{1,5}}
$$

\subsection{Model Verification and Validation}

Sensitivity analysis was conducted to quantify the influence of uncertainty in parameter values on the predictions. A range of values simulated to examine the future impact on the predictions of the model. In the sensitivity analysis of variables was seen, although the effect on the model changed only slightly in value.

Model calibration is the first stage testing or tuning of a model to a set of field and laboratory data. The data used is preliminary data that is not used in the formation of the original model. Purpose of calibration is to establish that the model can reproduce the results of field measurements. Calibration is performed with a set price parameters using trial and error.

Serves as the initial verification checks to assess the behavior of the model are as expected for a simple scenario (Dahl, 2001). Verification also serves to establish the range of confidence in the model using parameter values that have been calibrated in order to get a second field of data reproduction. Parameter evaluation done using chisquare methods (Schnoor, 1996).

$$
\underline{z}=\sum_{i=0}^{\pi} \frac{(y-r}{r}
$$

Where:

$\mathrm{X}^{2}=$ chi-square distribution;

$\mathrm{Y}_{\mathrm{obs}}=$ observation;

$\mathrm{Y}_{\text {model }}=$ simulation;

$\mathrm{n}=$ number of observation

In the validation phase, the behavior of the model compared to the new field data collected to determine whether the previous model predictions are still accurate. If the prediction model used is accurate, then the model is valid for the place.

\section{RESULTS AND DISCUSSION 3.1 Field data}

Comprehensive pollutant transport modelling, especially when relying on the fundamental advection equation for mass transport in rivers, requires a lot of experimental data. Field data will determine calibration and validation process. From the first sampling employed field data consists of channel characteristics measurements (river width, river depth, water velocity). With that field data river flow, river bed slope, shear velocity, and dispersion constant rate as shown on Table 1.

Table 1 River Pelawan hydrogeometry characteristics

\begin{tabular}{cccccc}
\hline Titik & $\mathrm{B}(\mathrm{m})$ & $\mathrm{H}(\mathrm{m})$ & $\mathrm{A}\left(\mathrm{m}^{2}\right)$ & $\mathrm{u}(\mathrm{m} / \mathrm{s})$ & $\mathrm{Q}\left(\mathrm{m}^{3} / \mathrm{s}\right)$ \\
\cline { 1 - 3 } \cline { 5 - 7 } & 15,15 & 4,219 & 63,91 & 0,368 & 23,52 \\
2 & 15 & 5,190 & 77,85 & 0,439 & 34,176 \\
3 & 16,1 & 4,203 & 67,66 & 0,354 & 23,95 \\
\hline
\end{tabular}

\begin{tabular}{rrrrr}
\hline $\mathrm{P}(\mathrm{m})$ & \multicolumn{1}{c}{$\mathrm{n}$} & \multicolumn{1}{c}{$\mathrm{S}(\mathrm{m} / \mathrm{m})$} & $\mathrm{U}^{*}(\mathrm{~m} / \mathrm{s})$ & $\mathrm{Ex}\left(\mathrm{m}^{2} / \mathrm{s}\right)$ \\
\hline 23,58 & 0,027 & $5,4 \mathrm{E}-04$ & 0,149 & 0,543 \\
25,38 & 0,023 & $3,13 \mathrm{E}-04$ & 0,126 & 0,729 \\
24,51 & 0,027 & $4,94 \mathrm{E}-04$ & 0,142 & 0,598 \\
\hline
\end{tabular}

Figure 3 Pattern of concentration change at Mercury concentration in water. Point 1 is the control point upstream, having the least Mercury concentration. Then after passing the mining site Mercury concentration at Point 2 and down on Point 3 downstream. The range of values of Mercury concentrations measured between 0.003-0.007 mg/l. The value is still far above the grade 3 grade, which is $0.002 \mathrm{mg} / \mathrm{l}$. From the results of the examination can be said Pelawan River is polluted when viewed from the parameter Mercury.

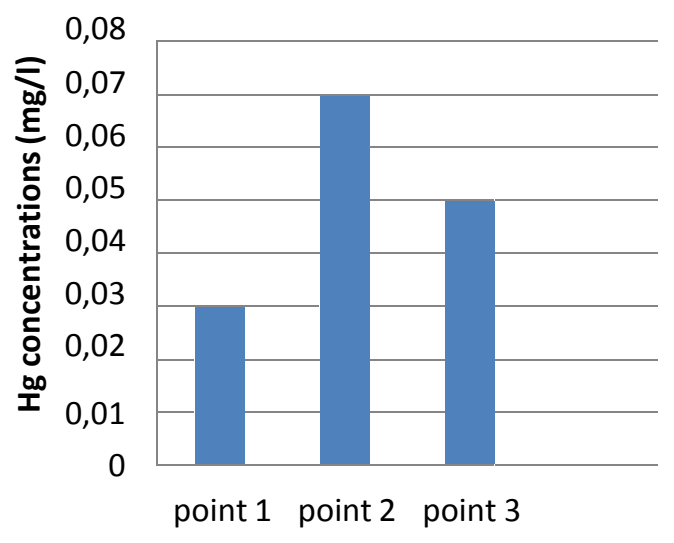

Fig.3 mercury concentrations

\subsection{Model Simulation}

Pollutant transport modeling in Pelawan river uses analytical solutions of advection-dispersion equations with semi-infinite pollutants. Assumed that the pollutant concentration initially has a zero value and then there is a sharp change due to input from the source, then the source releases the pollutant with a certain concentration constantly. The initial concentration of pollutants is assumed to be equal to the concentration of the measuring results at the three points. The rate of transformation used follows the first order kinetics. 


\subsection{Dimension Mercury Simulation}

Mercury is a pollutant with high solubility in water and includes a conservative pollutant, which means no biological degradation, assuming mercury is a conservative pollutant then the value of $\mathrm{k}=0$ /day or which means no mercury degradation. The result is shown in Figure 4, the concentration of mercury changes with distance to the source of the pollutant. The mercury concentration $0.007 \mathrm{mg} / \mathrm{l}$ corresponds to the initial concentration at Point 2 to a distance of 600 meters mercury $0.001 \mathrm{~m} / \mathrm{l}$. This does not correspond to the concentration of mercury obtained from the observation, therefore it is attempted to use the value of $\mathrm{k}=0.22$ /day assuming that the decrease of concentration occurs due to mercury absorption.

The result of the simulation shows that the mercury value of the model is close to the observed Mercury value. The presence of Mercury in water and also strongly influenced by the value of $\mathrm{Kd}$ or the distribution coefficient which shows the ratio between the metal adsorbed and the dissolved metal.

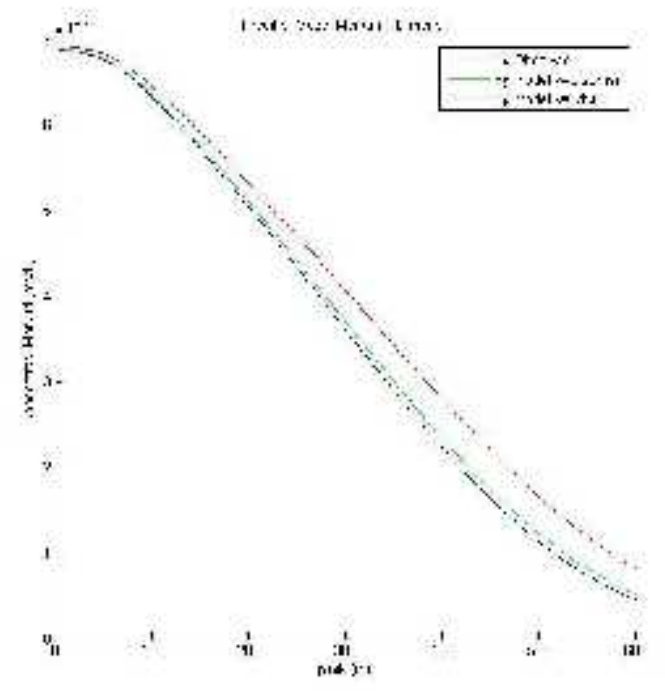

Fig.4 Simulation 1 Dimension mercury concentration with variation $\mathrm{k}$

The simulation is then done to find out the pattern of mercury distribution to $\mathrm{t}$ value (time) using $\mathrm{k}=0,22$ /day. At a distance of $100 \mathrm{~m}$, the mercury concentration reaches steady state at 1 hour 4 minutes. While at a distance of $600 \mathrm{~m}$, the mercury concentration reached the steady state condition at 5 hours 42 minutes, as shown in Figure 5.

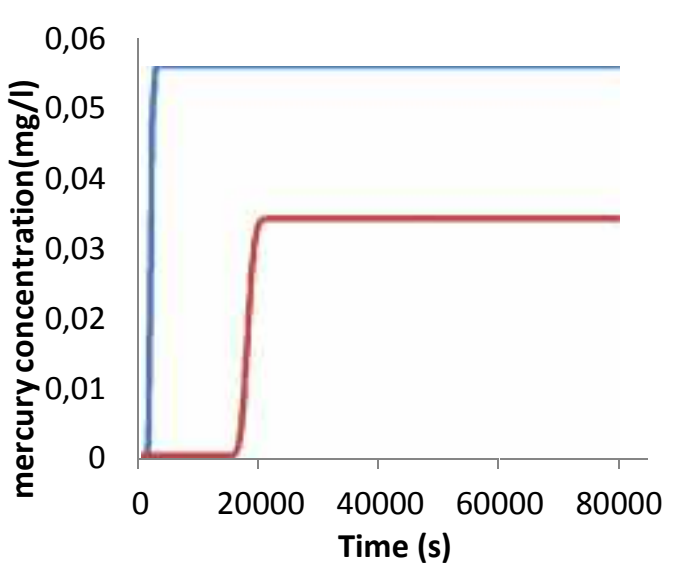

Fig.5 Simulation 1-D Concentration of Mercury with time

\section{CONCLUSION}

From the measurements at some point, it is known that the Pelawan river is polluted by mercury seen from the very large mercury value. The longer time $(\mathrm{t})$, the constant pollutant input makes the pollution load larger. Consequently the pollutant concentration at the larger $\mathrm{t}$ will decrease at a greater distance. Simulation results with $\mathrm{k}=0.22$ /day showed that the mercury value of the model was quite close to the concentration value of mercury result of observation.

\section{REFERENCES}

[1] Ani, E. C., Hutchins, M. G., Kraslawski, A. \& Agachi P. S. (2010). Assessment of Pollutant Transport and River Water Quality Using Mathematical Model. Rev. Roum. Chim 55 (4) : 285-291.

[2] Ani, E. C. (2010). Modeling of Pollutant Transport in Rivers : Process Engineering Approach. Ringkasan Tesis PhD. Babes-Bolyai University. Cluj-Napoca Romania.

[3] Afrianita, R. (2005). Simulasi Penyebaran COD dengan Menggunakan Metode Beda Hingga di Aliran Permukaan Bebas, Tesis Magister Program Magister Teknik Lingkungan. ITB. Bandung.

[4] Benedini, M. (2011). Water Quality Models for Rivers and Streams. State of the Art and Future Perspectives. Europian Water 34 : 27-40.

[5] Chapra, S. C., 1997. Surface Water-Quality Modeling. Singapura : McGraw-Hill Cmpanies, Inc.

[6] Dahl, M. \& Wilson, D. (2001). Modelling of Water Quality. Swedia : Karlstad University.

[7] Damanhuri, E. 1991. Peranan Kompos Sampah Kota dalam Mengurangi Kadar Karbon Organik dari Lindi, Lembaga Penelitian ITB. 
[8] Fjeld, R. A., Eisenberg, N. A., Compton, K. L. Quantitative Environmental Risk Analysis For Human Health. USA : John Wiley \& Son, Inc, Publication.

[9] Kamil, I. M. (2012). Bahan Kuliah Pemodelan Lingkungan. FTSL ITB.

[10] Kassenga G. R. \& Mbuligwe S. E. (2009). Impacts of a Solid Waste Disposal Site on Soil, Surface Water, and Groundwater Quality in Dar es Salaam City, Tanzania. Journal of Sustainable Development in Africa Vol. 10 : 73-94.

[11] Handiani, D.N. (2004). Studi Sirkulasi Arus dan Transpor Polutan Cobalt dan COD (Chemical Oxygen Demand) di Perairan Pantai Cilegon untuk Memonitor Buangan Limbah Industri. Tesis Magister Program Magister Teknik Lingkungan. ITB. Bandung.

[12] Kachiashvili, K., Gordeziani, G., Lazarov, R. \& Melikdzhanian, D. (2007). Modeling and Simulation of Pollutants Transport in Rivers. Applied Mathematical Modelling 31: 113711396

[13] Lü, F., Zhang, H.,Chang, C. H., Lee D. J. He, P. J., Shao L. M. \& Su, A. (2008). Dissolved Organic Matter and Estrogenic Potential of Landfill Leachate. Chemosphere 72 : 13811386.

[14] Notodarmojo, S. (2005). Pencemaran Tanah \& Air Tanah. Bandung: Penerbit ITB.

[15] Nubi, O. A., Osibanjo, O. \& Nubi, A. T. (2008). Impact Assessment of Dumpsite Leachate on The Qualities of Surface Water and Sediment of River Eku, Ona-Ara Local Government, Oyo State, Nigeria. Science World Journal 3 : 17-20.

[16] Schnoor, J. L. (1996). Environmental Modeling Fate and Transport of Pollutants in Water, Air, and Soil, New York : John Wiley \& Sons, Inc.

[17] Thomann, R.V. \& Mueller J. A. (1987). Principles of Surface Water Quality Modeling and Control. New York : Harper \& Row, Publishers, Inc. 